\title{
BLACK POINT OF WINTER WHEAT SEEDS
}

Goal. To study infection of seeds of winter wheat varieties by «black point» and to establish the phytopathogenic composition of pathogens in the Right Bank Forest-Steppe of Ukraine. Methods. Laboratory - macroscopic analysis was performed according to DSTU 4138-2002, phytopathogenic composition was identified using nutrient medium, statistical analysis of the obtained data - calculation of the degree of pathogen severity, HIP. Results. A collection of 27 varieties of soft winter wheat was studied to determine the degree of seed infection. The highest percentage of infection was found in varieties Vodogray Bilotserkivsky (Ukraine), Adele (Russia), Balitus (Austria), Viglanka (Slovakia), Sefeg-2 (Azerbaijan). The least susceptible to the disease are varieties Daria (Croatia), Bodycek (France), Gratsia Bilotserkivska (Ukraine, Bila Tserkva DSS), Azano (Sweden), Gospodarka (Ukraine), Kozyr (Ukraine), Morozko (Russia), the number of grains with signs of darkening in the embryonic zone for these varieties did not exceed $1 \%$. The sowing qualities of the diseased seeds were determined. The species composition of phytopathogens that cause the disease has been established. The phytopathogenic complex of seeds with the black point included fungi of the genera Alternaria, Fusarium, Curvularia, Bipolaris, Aspergillus, Acremoniella, Stemphillium, Sordaria and Epicoccum. Most often, the seeds were colonized by fungi of the genus Alternaria Nees. Their share in the years of research was 76.6-83.1\%. Conclusions. The infection of seeds of winter wheat varieties by black point under conditions of the Right-Bank Forest-Steppe of Ukraine in 2018-2019 ranged from 0 to $19.8 \%$ depending on the variety and year of research. The phytopathogenic complex included 13 species of fungi from 9 genera: Alternaria, Fusarium, Curvularia, Bipolaris, Aspergillus, Acremoniella, Stemphillium, Sordaria, Epicoccum. The part of Alternaria spp. in the years of research was over $75 \%$, the most common species were A. tenuissima and A. infectoria. The

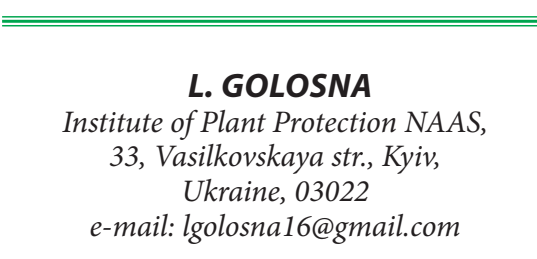

percentage of species from other genera was insignificant and did not exceed $4.6 \%$.

black point; winter wheat; phytopathogenic complex; Alternaria

Scientists from most countries where these crops have been grown for the last century have studied the cause of the appearance of cereals on seeds, especially wheat, and darkening of the embryo. Scientists from Australia, India, Argentina, Egypt, Lithuania, the United States, Canada, Russia, and others have shown great interest in this issue in the last decade. Their research is primarily aimed at studying the patterns of appearance of the dark color of the embryo depending on weather conditions, varietal characteristics and species composition of phytopathogens that cause its appearance.

Thus, the level of grain contamination of Egyptian wheat varieties ranged from $0,29 \%$ to $64 \%$. The most susceptible to damage were wheat varieties Sakha 8 and Sakha 93 , in which the number of affected embryos reached $64 \%$ and $63 \%$, respectively. More significant damage was observed in soft wheat varieties, durum wheat grain was affected by no more than $1,3 \%$. [1]. In a study of Pakistani varieties, it was found that the highest level of infection was in the variety Punjnad $-32.0 \%$, in Mehran-89 - 26.0\%, Fareed-08 $23.7 \%$ [2]. Canadian scientists have proven the influence of genetic characteristics of the variety on the level of infection of grain Cochliobolus sativus and Alternaria sp. with artificial infection [3].

Evaluation of the susceptibility of 58 varieties of spring durum

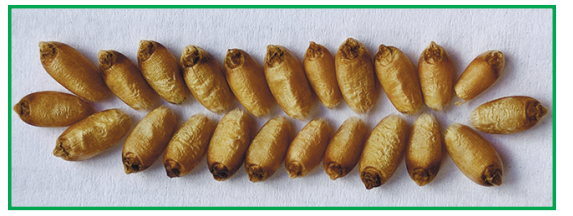

wheat to the manifestation of black point in the Altai Territory of Russia found that the average grain damage by black germ in 2014-2015 was $9.50 \%$, varying in genotypes from 2,75 to $30,00 \%$. The most affected varieties and lines were Lilek, Bezenchukskaya 205, 12S2-24, Bezenchukskaya 209, Bezenchukskaya steppe, Bezenchukskaya 210, Luchistaya, 12S1-14, Tverdynya, G1734, Pamyati Chekhovich, Saratovskaya Zolotistaya, Bezenchukskaya Zolotistaya. The lowest degree of damage was in the varieties: Salute Altai, Memory of Yanchenko, Altai amber, Solnechnaya 573, Angel, Omsk emerald, 1480d-2, Ray 25, Kharkov 46, Don Elegy, Orenburg 10, Divide [4].

In Ukraine, similar studies were also conducted in Polissya. The stability of 33 wheat samples from different countries was studied. The highest percentage of grains with black point was observed in the varieties Valencia (19\%), Tsarivna (13.8) and Lugastar (12.8\%). The highest resistance was shown by the Vyshivanka variety and Chinese samples (Zhongsi 1048 (D-227), Zhongsi 1258 (D-226) [5].

Most studies in the world have found that the main reason for the appearance of dark-colored germ in wheat is the penetration of fungi of the genus Alternaria into the germ zone during grain filling. Studies by Chinese scientists have shown that the most common genera of species of fungi that cause the appearance of black embryo are Alternaria (frequency of $56.7 \%$ ), Bipolaris (16.1\%) and Fusarium (6.0\%). The frequency of detection of fungi from the genera Curvularia, Aspergillus, Cladosporium, Exserohilum, Epicoccum, $\mathrm{Ni}$ grospora, Penicillium and Ulocladium ranged from 0.8 to $4.8 \%$ [6]. Fungi of the genus Alternaria (49.9\%), to a lesser extent Aspergillus (26.5), 
Drechslera (11\%), Fusarium (7.9\%), Cladosporium (3.8\%) and Curvularia were mainly found in Pakistan. $0.7 \%$ ) [6].

When studying seeds with a dark germ, a careful examination of the grains did not reveal any damage to the surface, which would improve the conditions for the penetration of fungi. B. sorokiniana and fungi of the genus Alternaria were isolated equally from apparently healthy grain and with signs of black point. Therefore, according to Mohsen Khani et all. The appearance of darkening was most likely the result of the plant's physiological response to environmental conditions during grain ripening [7].

Chinese scientists in vitro managed to obtain darkening in the area of the germ of wheat seeds, keeping it in a solution of catechol with the addition of $\mathrm{H}_{2} \mathrm{O}_{2}$. When the extract of the fungus $\mathrm{B}$. sorokiniana was added to the medium, the degree of darkening increased. According to them, the cause of this phenomenon is the fermentation process with the accumulation of phenolic compounds in the grain, in particular in the embryonic zone enhanced by the presence of the fungus $B$. sorokiniana [8].

Contradictory data are found in the literature on the effect of embryo darkening on sowing qualities. Thus, Poonam Rani and Anita Singh from India conducted a study on the effect of the degree of darkening of the grain in the germ zone on its germination. It was found that seed germination where the darkening is more than $1 / 2$ germ reduces germination by 75 percent or more depending on the variety [9].

Analysis of literature sources in recent years indicates the need for such research in Ukraine. The role of dark grain color in the germ zone has not yet been fully studied. The analysis of local varieties will allow to assess their resistance - susceptibility to damage by pathogens of black embryo and to develop measures to reduce the development of this disease during grain maturation.

Materials and methods of research. To study the degree of damage to the seeds of winter wheat black point was used a collection of varieties from the National Center for Plant Genetic Resources of Ukraine Institute of Plant Breeding V.Ya. Yuryeva. The collection was sown during 2018-2019 at the research site of the Institute of Plant Protection of NAAS in the Research and Production Department of the Institute of Physiology and Genetics of NASU, p. Glevakha, Vasylkiv district of Kyiv region. Macroscopic analysis for the detection of seeds with signs of dark color in the area of the embryo was performed according to DSTU 41382002 [10].

Selected seeds with a black point were sown on a selective nutrient agar. Since a significant proportion of fungi that cause black germ belong to the genus Alternaria used potato carrot agar (PCA). Incubation was performed at a temperature of $22-25^{\circ} \mathrm{C}$ under fluorescent lamps. Identification of the species composition of phytopathogens from seeds with black point was performed 10-14 days after sowing. Species affiliation of fungi of the genus Alternaria was determined by several parameters: morphological and cultural features, sporulation habit and size and structure of conidia [11]. Other species were identified by morphological features of conidia using a microscope according to reference books [12, 13, 14].

Sowing suitability of seeds with black germ was determined according to DSTU 4138-2002 [10]. The seeds were sown between layers of filter paper in the plant and germinated at a temperature of $20^{\circ} \mathrm{C}$. Germination energy was determined on the 4-th, and germination on the 8-th day after sowing, the development of phytopathogens was observed on the 10-th day. The obtained research results were statistically processed in the Exel program.

Results and discussion. In 2018-2019, the degree of damage to soft winter wheat seeds by the black point in the conditions of the RightBank Forest-Steppe of Ukraine was studied. 27 varieties were analyzed, of which 15 - local selection, others - from Croatia, France, Sweden, Russia, Slovakia, Azerbaijan and Austria.

The degree of damage to varieties in 2018 ranged from 0 to $10.74 \%$, and in 2019 from 0 to $19.8 \%$ depending on the variety and conditions of the year. The average number of grains with signs of black point was $3.12 \%$ in 2018 and $3.42 \%$ of the analyzed seeds in 2019, respectively (Table 1). Most varieties had a low degree of black embryo damage.

The highest percentage of seeds with signs of black germ in 2018-2019 was observed in varieties Pyshna (Ukraine, IR) $-4.68 \%$,

Table 1. Defeat of seeds of winter wheat varieties by black germ (Kyiv region, 2018-2019)

\begin{tabular}{|c|c|c|c|c|c|}
\hline \multirow[b]{2}{*}{ № } & \multirow[b]{2}{*}{ Variety name } & \multirow[b]{2}{*}{ Origin } & \multicolumn{3}{|c|}{ Blakc point seeds, $\%$} \\
\hline & & & 2018 & 2019 & $\begin{array}{l}\text { aver- } \\
\text { age }\end{array}$ \\
\hline 1 & Daria & Croatia & 0.5 & 0 & 0.25 \\
\hline 2 & Bodycek & France & 0.72 & 0 & 0.36 \\
\hline 3 & $\begin{array}{l}\text { Grace of } \\
\text { Bila Tsercva }\end{array}$ & Ukraine & 0 & 0.89 & 0.45 \\
\hline 4 & Azano & Sweden & 0.48 & 0.63 & 0.6 \\
\hline 5 & Hospodarka & Ukraine & 1.18 & 0 & 0.6 \\
\hline 6 & Kozyr & Ukraine & 1.24 & 0 & 0.6 \\
\hline 7 & Morozko & Russia & 0.96 & 0.34 & 0.7 \\
\hline 8 & Donera & Russia & 1.5 & 0.56 & 1.0 \\
\hline 9 & Klad & Ukraine & 1.64 & 0.48 & 1.0 \\
\hline 10 & Prydniprovska & Ukraine & 0.7 & 2.27 & 1.1 \\
\hline 11 & Argument & Ukraine & 1.26 & 1.42 & 1.3 \\
\hline 12 & Vozdvygenka & Ukraine & 1.68 & 1.57 & 1.6 \\
\hline 13 & Sotnycia & Ukraine & 3.26 & 1.15 & 2.2 \\
\hline 14 & Sich & Ukraine & 2.28 & 2.18 & 2.2 \\
\hline 15 & Korovayna & Ukraine & 3.16 & 1.44 & 2.3 \\
\hline 16 & Perlyna Polissya & Ukraine & 1.4 & 3.37 & 2.4 \\
\hline 17 & Kesaria podilska & Ukraine & 5.1 & 3.56 & 5.0 \\
\hline 18 & Vyd & Russia & 3.32 & 2.99 & 3.2 \\
\hline 19 & Kubok & Ukraine & 4.94 & 1.38 & 3.16 \\
\hline 20 & Tabor & Russia & 2.56 & 3.95 & 3.3 \\
\hline 21 & Pushna & Ukraine & 4.66 & 4.7 & 4.7 \\
\hline 22 & Donna & Russia & 7.74 & 2.2 & 4.9 \\
\hline 23 & Adel & Russia & 5.68 & 8.07 & 6.9 \\
\hline 24 & $\begin{array}{l}\text { Vodogray of } \\
\text { Bila Tsercva }\end{array}$ & Ukraine & 5.1 & 8.82 & 6.9 \\
\hline 25 & Viglanka & Slovenia & 4.98 & 14.4 & 9.7 \\
\hline 26 & Balitus & Austria & 3.62 & 18.1 & 10.9 \\
\hline 27 & Sefeg-2 & Azerbaijan & 10.74 & 19.8 & 15.3 \\
\hline \multicolumn{3}{|c|}{ Average } & 3.12 & 3.42 & 3.27 \\
\hline \multicolumn{3}{|c|}{$\mathrm{LSD}_{05}$ by factor «grade» } & \multicolumn{3}{|c|}{6.0} \\
\hline \multicolumn{3}{|c|}{$\mathrm{LSD}_{05}$ by factor «year» } & \multicolumn{3}{|c|}{1.6} \\
\hline
\end{tabular}


Vodogray Bila Tserkva (Ukraine, BC DSS) - 6.9\%, Adele (Russia, Krasnodar Research Institute of agricultural) $-6.9 \%$, Balitus (Austria) $10.9 \%$, Viglanka (Slovakia) - 9\%, Sefeg-2 (Azerbaijan) - 15.3\%. The least susceptible to the disease were varieties Daria (Croatia) $-0.25 \%$, Bodycek (France) $-0.36 \%$, Grace Bila Tserkva (Ukraine, Bila Tserkva DSS) $-0.45 \%$, Azano (Sweden), Gospodarka (Ukraine, IFRiG ) and Kozyr (Ukraine, SGI) by $0.6 \%$, Morozko (Russia, Krasnodar Research Institute of agricultural) $-0.7 \%$.

From the analyzed collection, the seeds of the varieties that were most affected by the black germ during the years of research were selected: Pyshna, Caesarea Podilska, Vodogray Bila Tserkva, Adele, Viglanca, Sefeg-2. The influence of black point seed damage on sowing qualities of these varieties was studied. As a result of research it was found that the germination energy and germination of these varieties in the years of research ranged from 90 to $100 \%$ depending on the variety and year of research (Table 2). The seeds had good germination rates and therefore the effect of darkening in the embryonic zone did not show a significant effect on germination.

Analysis of seeds with signs of black embryo for pathogenic microflora revealed significant damage by pathogens of fungal etiology and bacterial infection. The phytopathogenic complex included 13 species of fungi from 9 genera. Thus, fungi from the genera Alternaria, Fusarium, Curvularia, Bipolaris, Aspergillus, Acremoniella, Stemphillium, Sordaria and Epicoccum were found (Fig. 1).

The most common fungi were of the genus Alternaria, which accounted for $76.5 \%$ in 2018 and $83.1 \%$ in 2019 . In 2018, two species of the genus Alternaria Alternaria tenuissima $-37.5 \%$ and Alternaria infectoria - $39 \%$ were identified on wheat grain with black germ. In 2019, 4 species were identified - Alternaria tenuissima - 41.5\%, Alternaria infectoria - 35.4\%, Alternaria alternata $-2.3 \%$ and Alternaria sp. $-3.8 \%$.

The share of other species in 2018 was $23.5 \%$, most often of which were isolated fungi from the genera Fusarium $3.1 \%$, Stemphillium $4.7 \%$, Sordaria $7.8 \%$ and
Table 2. Laboratory germination of winter wheat seeds with signs of black point harvest 2018-2019

\begin{tabular}{|c|l|c|c|c|c|}
\hline \multirow{2}{*}{ № } & \multirow{2}{*}{ Variety name } & \multicolumn{2}{|c|}{ Germination energy, \% } & \multicolumn{2}{c|}{ Similarity, \% } \\
\cline { 3 - 6 } & & $\mathbf{2 0 1 8}$ & $\mathbf{2 0 1 9}$ & $\mathbf{2 0 1 8}$ & $\mathbf{2 0 1 9}$ \\
\hline 1 & Pushna & 90 & 100 & 90 & 100 \\
\hline 2 & Kesaria Podilska & 95 & 95 & 100 & 95 \\
\hline 3 & Vodogray of Bila Tsercva & 90 & 100 & 100 & 100 \\
\hline 4 & Adel & 95 & 100 & 95 & 100 \\
\hline 5 & Viglanca & 100 & 95 & 95 & 95 \\
\hline 6 & Sefeg-2 & 100 & 100 & 100 & 100 \\
\hline
\end{tabular}

species that did not form sporulation $6.3 \%$. In 2019, fungi from the genera Aspergillius $4.6 \%$, Sordaria $3.8 \%$, Epicoccum $2.3 \%$, Stemphillium $1.5 \%$, Acremoniella $0.8 \%$, Fusarium $0.8 \%$, Bipolaris $1.5 \%$ and bacterial infection $1.5 \%$, the share of which was $17 \%$.

Detected fungi have different etiologies, so the species Alternaria, Fusarium, Bipolaris can cause disease in plants and are pathogens of seeds, which often affect sowing qualities and cause the accumulation of mycotoxins. The species Curvularia, Aspergillus, Acremoniella, Stemphillium, Sordaria and Epicoccum act as saprophytes and usually settle on dead tissues or plant remains.

Fungi of the genus Alternaria, most often found on the seeds of major cereals. The seeds usually affect small-spore species Alternaria tenuissima and a complex of species Alternaria infectoria (Photo 1),
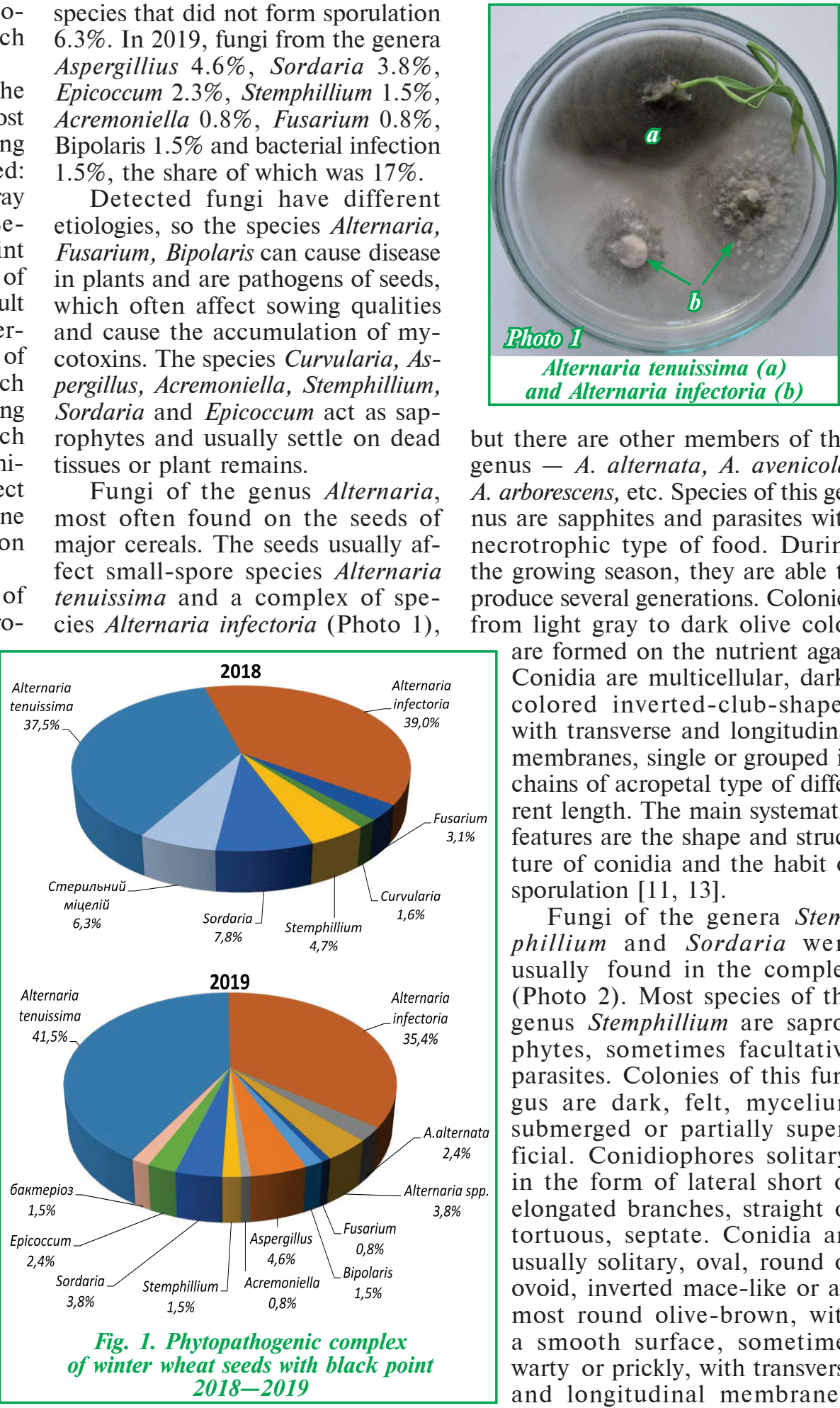

but there are other members of this genus - A. alternata, $A$. avenicola, $A$. arborescens, etc. Species of this genus are sapphites and parasites with necrotrophic type of food. During the growing season, they are able to produce several generations. Colonies from light gray to dark olive color are formed on the nutrient agar. Conidia are multicellular, darkcolored inverted-club-shaped with transverse and longitudinal membranes, single or grouped in chains of acropetal type of different length. The main systematic features are the shape and structure of conidia and the habit of sporulation $[11,13]$.

Fungi of the genera Stemphillium and Sordaria were usually found in the complex (Photo 2). Most species of the genus Stemphillium are saprophytes, sometimes facultative parasites. Colonies of this fungus are dark, felt, mycelium submerged or partially superficial. Conidiophores solitary, in the form of lateral short or elongated branches, straight or tortuous, septate. Conidia are usually solitary, oval, round or ovoid, inverted mace-like or almost round olive-brown, with a smooth surface, sometimes warty or prickly, with transverse and longitudinal membranes, 
with one or more constrictions, with a scar (Photo 3) [13, 14]

Fungi of the genus Sordaria are representatives of coprophilous fungi, usually do not have conidial sporulation. Form dark brown or black pearshaped perithecia (Photo 4). Bags are cylindrical, contain 8 dark green or dark brown ellipsoidal ascospores [12].

The complex of Aspergillius species on the surface of the seed acts as a saprotroph, but in case of noncompliance with storage conditions or under unfavorable germination conditions can cause seed mold. Manifested in the form of powdery heads of different colors with a mass of spherical spores located on the fialids. Species of this genus are highly toxin-forming and in the process of their vital activity produce a number of poisonous substances - aflatoxins, ochratoxins, fumizinin, trichothecins, and others. Metabolites that form these fungi cause diseases of the internal organs of animals and humans by exhibiting neurotoxic, hepatotoxic and nephrotoxic effects [15].

Often the main causative agent of the black point is the species Bipolaris sorociniana, which is a member of the genus Bipolaris (Photo 5). The penetration of the mycelium of this fungus under the shell of the embryo causes its darkening. The degree of darkening depends on the depth of the mycelium. Grain affected by this fungus is usually thin, underdeveloped has low germination rates. This pathogen affects more than 90 species of cereals. In addition to seeds, it can infect leaves in the form of dark brown spots and the basal part of the stem, causing the development of root rot $[13,15]$.

Colonies of the fungus of the genus Curvularia are dark (gray, brown or almost black), velvety, immersed in the substrate. Conidia solitary, irregularly shaped, often curved, mace-like, ellipsoidal, broadly spindle-shaped, have three or more membranes. They mostly cause black spotting in cereals, but can affect seeds [13].

Epicoccum colonies were rarely detected in samples. On the surface of the medium, they formed a sporology with dark-colored spherical unicellular warty conidia on short conidiophores (Photo 6). Usually pathogens of this genus are the causative agents of leaf spot on corn and other plants can cause the destruction of wood [13].

Another species that is quite rare in our samples of wheat seeds was Acremoniella atra. This species affects a wide range of plants, causing root rot and leading to significant
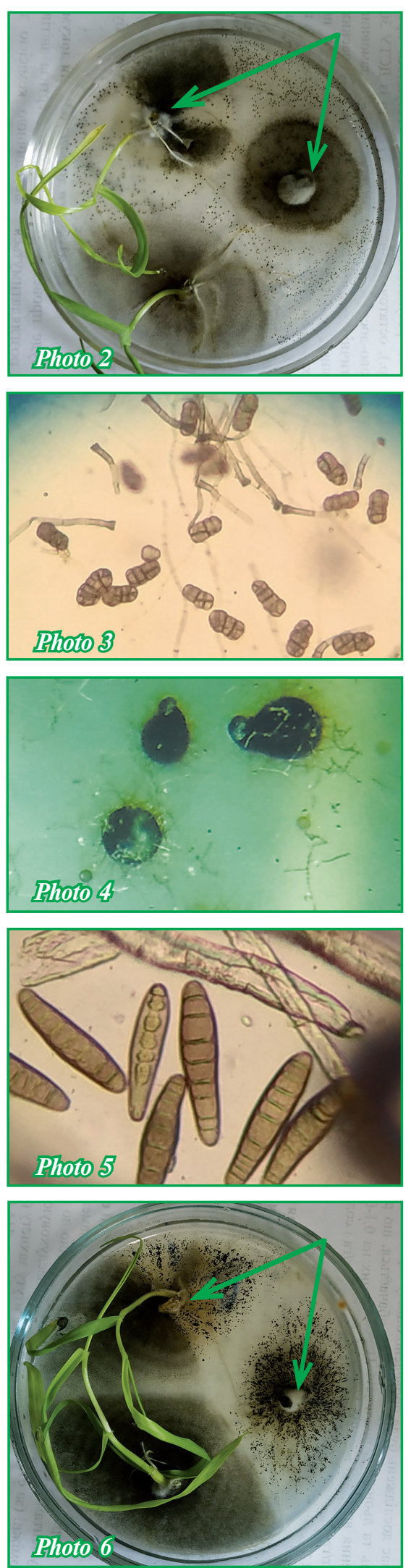

crop losses. On the environment it is shown in the form of air fluffy mycelium, at first light, in due course brown. Forms single unicellular globular light brown conidia with double shell [13].

The amount of grain with a darkcolored germ is regulated by DSTU 3768: 2019. Depending on the seed class, its number should not exceed $8 \%$ in durum wheat of grades $1-3$ and $30 \%$ in durum wheat, and in durum wheat seeds they should be absent altogether. Therefore, selection on this basis, especially in durum wheat is of great importance [10].

\section{CONCLUSIONS}

The degree of damage to winter wheat seeds black point in the zone of the Right Bank Forest-Steppe of Ukraine in 2018-2019 was studied. The highest percentage of seeds with black point $(6.9-15.3 \%)$ was found in varieties Vodogray Bila Tserkva (Ukraine, BC DSS) - 6.9\%, Adele (Russia, Krasnodar Research Institute of agricultural), Balitus (Austria), Viglanka (Slovakia), Sefeg-2 (Azerbaijan).

The least susceptible to the disease are Daria (Croatia), Bodycek (France), Grace Bila Tserkva (Ukraine, Bila Tserkva DSS), Azano (Sweden), Gospodarka (Ukraine, IFRIG) and Kozyr (Ukraine, SGI), Morozko (Russia, Krasnodar) NDISG), the number of grains with signs of darkening in the embryonic zone did not exceed $1 \%$ in the years of research.

Phytopathogenic complex of winter wheat seeds with signs of darkening in the germ zone in the Right Bank Forest-Steppe of Ukraine in 2018-2019 included 13 species of fungi from 9 genera: Alternaria, $F u$ sarium, Curvularia, Bipolaris, Aspergillus, Acremoniella, and Stemphillium.

\section{REFERENCE}

1. Ibrahim S. Draz, Shokry M. El-Gremi, Wassief A. Youssef. (2016). Response of Egyptian wheat cultivars to kernel black point disease alongside grain yield Pak. J. Phyto pathol, Vol. 28 (01) 15-17, P. 13-17. URL: https://www.pjp.pakps.com/index.php/PJP/ issue/view/9

2. Nasreen Sultana, Khalil Ahmed Khanzada, Muhammad Talha Azeem (2019). Black point of wheat in commercial varieties of Sindh. Pakistan. International journal of biology and biotechnology 16 (2): 385-389. P. 385-389. URL https://ijbbku.com/16-2-19.php 
3. Connert R.L., Davidson J.C.N. (1988) Resistance in wheat to black point caused by Alternaria alternata and Cochliobolus sativus. Can. J. Plant Sci. Vol 68. P. 351-359. https:// cdnsciencepub.com/doi/abs/10.4141/cjps88046

4. Barysheva N.V., Rozova M.A., Zi borov A.I., Khlebova L.P., Kraynov A.P. (2016). Ustoychivost' genotipov tverdoy pshenitsy $\mathrm{k}$ chernomu zarodyshu Acta Biologica Sibirica. [Resistance of durum wheat genotypes to the black embryo of Acta Biologica Sibirica]. 2 (4). S. 45-51. URL: https://cyberleninka.ru/ article/n/ustoychivost-genotipov-tverdoy-pshenitsy-k-chernomu-zarodyshu5 (in Russian).

5. Rozhkova T., Burdulaniuk A., Vlasenko V., Nemerytska L. Perspektyvnist poshuku dzherel stiikosti pshenytsi ozymoi do chornoho zarodka. [Prospects for finding sources of resistance of winter wheat to black germ] Visnyk Lvivskoho natsionalnoho ahrarnoho universytetu. Seriia: Ahronomiia. Vyp. 22 (1). S. 39-46.URL: http://repo.snau.edu.ua/ bitstream/123456789/6029/1/Рожкова\%20 T.O.\%20CHAY.pdf6 (in Ukrainian).

6. Kai-Ge Xu, Yu-Mei Jiang, Yang-Kun Li Qi ao-Qiao Xu, Ji-Shan Niu, Xin-Xin Zhu, Qiao Yun Li. (2018). Identification and Pathogenic ity of Fungal Pathogens Causing Black Point in Wheat on the North China Plain. Indian Microbiol. Vol. 58(2). P. 159-164. https://doi. org/10.1007/s12088-018-0709-1

7. Mohsen Khani, Judy Cheong, Kolum bina Mrva, Daryl Mares. (2018). Wheat black point: Role of environment and genotype. Jour nal of Cereal Science. Vol. 82. P. 25-33. https:// doi.org/10.1016/j.jcs.2018.04.012

8. Qiaoyun Li, Kaige Xu, Siyu Wang, Mengyu Li, Yumei Jiang, Xiaolong Liang, Jis han Niu, Chenyang Wang. (2020). Enzymatic Browning in Wheat Kernels Produces Symptom of Black Point. Caused by Bipolaris sorokin iana Frontiers in Microbiology. Vol. 11. P. 1-12. https://doi.org/10.3389/fmicb.2020.526266

9. Poonam Rani, Anita Singh. (2018). Effect of Black Point Infection on Germination of different varieties of Wheat Seed. International Journal of Advanced Scientific Research and Management, Special Issue I, Jan 2018. P. 149151. URL: http://ijasrm.com/wp-content/uploads/2018/03/IJASRM_V3S1_433_149_151. pdf 10

10. Nasinnia silskohospodarskykh kultur Metody vyznachannia yakosti: DSTU 4138 2002. [Seeds of agricultural crops. Methods for determining quality: DSTU 4138-2002.] Kyiv: Derzhspozhyvstandart Ukrainy, 2003. 173 s. URL: https://www.studmed.ru/dstu4138-2002-nasnnya-slskogospodarskih-kulturmetodi-viznachennya-yakost_e073265435f html (in Ukrainian)

11. Gannibal F.B. Monitoring al'ternariozov sel'skokhozyaystvennykh kul'tur i identifikatsiya vidov gribov roda Alternaria. [Alternaria monitoring of agricultural crops and identification of species of fungi of the genus Alternaria]. Metodicheskoe posobie. Sankt-Peterburg. 2011. 71 s. (in Russian).

12. Tsuneo Watanabe. (2002). Pictorial Atlas of Soil and Seed Fungi Morphologies of Cultured Fungi and Key to Species Second
Edition CRC PRESS Boca Raton London New York Washington, D.C. 486 p.

13. Bilay V.I. (1988). Mikroorganizmy vozbuditeli bolezney rasteniy. Spravochnik. [Microorganisms - causative agents of plant diseases. Directory]. Kyiv: Naukova dumka. 508 s. (in Russian).

14. Pidoplichko N.M. (1977). Griby parazity kul'turnykh rasteniy. Tom 2 . Griby nesovershennye. [Fungi are parasites of cultivated plants. Volume 2. Mushrooms imperfect]. Kyiv: Naukova dumka. 300 s. (in Russian).

15. Kyryk M.M., Pikovskyi M.I. (2012). Patolohiia nasinnia silskohospodarskykh kultur. [Pathology of seeds of agricultural crops]. Kyiv: Druk «TsP «KOMPRYNT». 212 s. (in Ukrainian).

\section{Голосна Л.М.}

Інститут захисту рослин НААН,

вул. Васильківська, 33, м. Київ

03022, Україна,

e-mail:lgolosna16@gmail.com

\section{Чорний зародок насіння пшениці} озимої

Мета. Дослідити ураження насіння сортів пшениці озимої чорним зародком та встановити бітопатогенний склад збудників захворювання в умовах Киїської області (Правобережний Лісостеп Украӥни). Методи. Лабораторні - макроскопічний аналіз виконували згідно з ДСТУ 4138-2002; склад фітопатогенів ідентибіковували з використанням живильного середовища. Статистичний - аналіз одержаних даних, розрахунок ступеня ураження збудниками, НІР. Результати. Для виявлення ступеня ураження насіння чорним зародком досліджено колекиію 3 27-ми сортів пшениці озимої м'якої. Найбільше ураженими були сорти Водограй білоиерківський (Україна), Адель (Росія), Balitus (Австрія), Viglanka (Словаччина), Sefeg-2 (Азербайджан) - ураження понад $6 \%$ в середньому за роки дослідженъ. Найменш сприйнятливі до захворювання сорmu Daria (Хорватія), Bodycek (Франція), Грація білочерківська (Україна, Білочерківська ДСС), Аzапо (Швеція), Господарка (Украӥна), Козир (Украӥна), Морозко (Росія). Кількість зерен з ознаками потемніння в зоні зародка у них не перевишувала $1 \%$. Визначено посівні якості ураженого хворобою насіння. Встановлено видовий склад бітопатогенів, які спричинюють прояв захворювання. Ідентибіковано гриби 3 родів Alternaria, Fusarium, Curvularia, Bipolaris, Aspergillus, Acremoniella, Stemphillium, Sordaria ma Epicoccum. Найчacтіше насіння колонізували гриби з роду Alternaria Nees. Їx частка в роки досліджень становила 76,6-83,1\%. Висновки. Ураження насіння сортів пшениці озимої чорним зародком в умовах Київськоӥ області (Правобережний Лісостеп України) у 2018-2019 рр. варіювало від о до 19,8\% залежно від сорту та року досліджень. Фітопатогенний комплекс включав 13 видів грибів з 9-ти родів. Частка грибів 3 роду Alternaria y роки досліджень становила понад 75\%, найчастіше виявляли види A. tenuissima (Kunze) Wiltshire ma
A. infectoria E.G. Simmons. Частка видів з інших родів була незначною і не перевишувала $4,6 \%$.

чорний зародок; пшениця озима; фітопатогенний комплекс; Alternaria

Голосна Л.Н.

Институт защиты растений НААН, ул. Васильковская, 33, г. Киев, 03022, Украина,

e-mail:lgolosna16@gmail.com

Чорный зародыш семян пшеницы озимой

Цель. Изучить пораженность семян различных сортов пшеницы озимой чер ным зародышем и установить фитопа тогенный состав возбудителей заболевания в условиях Правобережной Лесостепи Украчны. Методы. Лабораторнье - макроскопический анализ выполняли согласно ДСТУ 4138-2002; состав фитопатогенов идентифииировали с использованием питательной среды. Статистический анализ полученных данных, расчет пораженности семян возбудителями, рассчет НСР. Результаты. Для выявления поражённости семян черным зародышем исследовали коллекиию из 27-ми сортов пшениць мягкой озимой. Наибольший прочент поражения обнаружен у сортов Водограй белоиерковский (Украина), Адель (Россия), Balitus (Австрия), Viglanka (Словакия), Sefeg-2 (Азербайджан). Наименее восприимчивыми к заболеванию отме чены сорта Daria (Хорватия), Bodycek (Франиия), Грачия белочерковская (Украина, Белоиерковская ДСС), Аzапо (Швеичия), Хозяйка (Украина), Козьрь (Украина), Морозко (Россия). Количество зерен с признаками потемнения в зоне зародыша у этих сортов не превышало 1\%. Определены посевные качества пораженного болезнью семян. Установлен видовой состав фитопатогенов, вызывающих проявление заболевания. Фитопатогенный комплекс семян с черным зародышем включал грибы uз родов Alternaria, Fusarium, Curvularia Bipolaris, Aspergillus, Acremoniella, Stemphillium, Sordaria u Epicoccum. Чаще всего семена колонизировали грибы из рода Alternaria Nees. Их часть составилала 76,6-83,1\%. Выводы. Поражение семян сортов пшенииь озимой черным зародышем в условиях Правобережной Лесостепи Украинь в 2018-2019 г2. варьировало от о до 19,8\% в зависимости от сорта и года исследований. Фитопатогенньй комплекс включал 13 видов грибов с 9-ти родов: Alternaria, Fusarium, Curvularia, Bipolaris, Aspergillus, Acremoniella, Stemphillium, Sor daria, Epicoсcum. Часть грибов из рода Alternaria в годы исследований составляла более 75\%, преобладали видь A. tenuissima и A. infectoria. Количество видов из других родов было незначительным и не превышало 4,6\%.

чорный зародыш; пшеница озимая; фитопатогенний комплекс; Alternaria

Received on 22.07.2021 